\title{
Comparative seasonal assessment of pollution and health risks associated with heavy metals in water, sediment and Fish of Buriganga and Turag River in Dhaka City, Bangladesh
}

\author{
M. N. Hossain ${ }^{1}$ (D) Ashiqur Rahaman² - Md. Jawad Hasan² - Md. Minhaz Uddin² Nazma Khatun $^{3}$. \\ Sayed Md. Shamsuddin ${ }^{2,4}$
}

Received: 6 November 2020 / Accepted: 4 March 2021 / Published online: 29 March 2021

(c) The Author(s) 2021 OPEN

\begin{abstract}
Heavy-metal pollution of surface water, sediment and fish have been seen as a major global problem, with a significant proportion of developing countries like Bangladesh. This study assessed the intensity of alarming six toxic substances ( $\mathrm{Cr}, \mathrm{Zn}, \mathrm{Fe}, \mathrm{Cu}, \mathrm{Pb}$ and $\mathrm{Ni}$ ) throughout the River water, sediments as well as soft tissues of three widely consumed fishes (Heteropneustes fossilis, Channa punctatus and Channa striata) obtained from two urban streams of the Buriganga and Turag in the Dhaka metropolitan. For evaluating the comparative seasonal variation of heavy-metal concentration, water and sediment samples were collected from five selected sites for two different seasons (viz. 10 from winter seasons and 10 from summer seasons). Finally, a total of 20 water samples, 20 sediment and 12 fish samples were investigated by flame atomic absorption spectroscopy (FAAS) and graphite furnace atomic absorption spectrometer (GFAAS) corrected with the Zeeman effect background correction system. The hierarchy of mean concentration of selected heavy metals in Buriganga water is found to be $\mathrm{Fe}>\mathrm{Cr}>\mathrm{Ni}>\mathrm{Zn}>\mathrm{Cu}>\mathrm{Pb}$ in the winter season whereas during the summer season the order is $\mathrm{Fe}>\mathrm{Cr}>\mathrm{Zn}>\mathrm{Ni}>\mathrm{Cu}>\mathrm{Pb}$. For the River Turag, the order is $\mathrm{Fe}>\mathrm{Zn}>\mathrm{Cu}>\mathrm{Ni}>\mathrm{Cr}>\mathrm{Pb}$ and $\mathrm{Fe}>\mathrm{Zn}>\mathrm{Ni}>\mathrm{Cu}>\mathrm{Cr}>\mathrm{Pb}$ during winter and summer season, respectively. The level of metals studied surpassed the acceptable level of drinkable water, implying the ineptitude of drinking and cooking water from these Rivers. However, this hierarchy of heavy metals for sediments of Buriganga River changed to $\mathrm{Fe}>\mathrm{Cr}>\mathrm{Ni}>\mathrm{Zn}>\mathrm{Cu}>\mathrm{Pb}$ for the winter season and $\mathrm{Fe}>\mathrm{Cr}>\mathrm{Ni}>\mathrm{Cu}>\mathrm{Zn}>\mathrm{Pb}$ for the summer season. Whereas, for the Turag River, the decreasing trend of metal concentration found in sediment was $\mathrm{Fe}>\mathrm{Zn}>\mathrm{Cr}>\mathrm{Ni}>\mathrm{Cu}>\mathrm{Pb}$ for both seasons. For probable human health hazard implications, contamination factor (CF) and pollution load index (PLI) were studied. The CF values revealed the low-to-moderate pollution of sediment. The PLI value above one shows the degradation of the consistency of the sediments. $\mathrm{Fe}, \mathrm{Ni}, \mathrm{Pb}, \mathrm{Cr}, \mathrm{Zn}$ and $\mathrm{Cu}$ concentrations in fish species were found to be 19.66-45.1, 0.07-12.18, 1.2-10.18, 20.18-187.07, 11.08-68.25, 2.07-10.4 mg/kg, respectively. The metals studied differed considerably among organisms and seasons. Bioconcentration factor (BCF), the daily average consumption of metal (EDI), as well as target threat quotients (THQs) for specific metal indicated that $\mathrm{Cr}$ and $\mathrm{Pb}$ are harmful in fish muscles and possible risks remain for fish consumers. The obtained concentrations of some metals are higher than the WHO/FAO's permissible limit, suggesting that the water and fish found in these Rivers are like to be harmful to the human being. This study shows that attention should be given to the risk assessment for heavy metals in these Rivers.
\end{abstract}

Keywords Heavy-metal · Pollution · Health-risk · Fish

M. N. Hossain, nazmul.hossain.gce.buet@gmail.com; $₫$ Nazma Khatun, nazmabaec@gmail.com | ${ }^{1}$ Department of Glass and Ceramic Engineering (GCE), Bangladesh University of Engineering and Technology (BUET), Dhaka, Bangladesh. ${ }^{2}$ Institute of Leather Engineering and Technology, University of Dhaka, Dhaka, Bangladesh. ${ }^{3}$ Atomic Energy Centre, Chattogram, Bangladesh Atomic Energy Commission, Chattogram 4209, Bangladesh. ${ }^{4}$ Department of Applied Chemistry and Chemical Engineering, University of Dhaka, Dhaka, Bangladesh. 


\section{Introduction}

Heavy-metal contamination is considered among the most prominent problems that endanger water quality [1-3]. Increased manufacturing activities [2], unsustainable farming practices [4], constant dumping of urban wastewater [5] and unnecessary traffic activities [6] lead to heavy-metal contamination of ecosystems. The heavymetal pollution in the atmosphere has now become a global concern, attributed to the growing pollution of water, soil including food in so many places around the world. Pollution poses a tremendous hazard to the availability of drinking water. This pollution often constitutes a risk to the environment and human health through the ingestion of aquaculture $[7,8]$. The United Nations Agenda 2030 and Sustainable Development Goals (SDGs) have put a clear emphasis on the aim to "by 2030, improve water quality by reducing pollution, eliminating dumping and minimizing release of hazardous chemicals and materials, halving the proportion of untreated wastewater and substantially increasing recycling and safe reuse globally" [9].

A large amount of toxic wastewater was dumped into the lower land and water sources every day in Bangladesh. Besides, the Riverine aquatic ecosystem receives a significant amount of suspended materials polluted by heavy metals from the nearby country via the Teesta and Brahmaputra Rivers. Thereupon, it poses a serious threat to fisheries and other marine biotas [10].

In a developing country like Bangladesh, River pollution has become an alarming issue. Hundreds of factories discharge their waste products into nearby Rivers. The effluent coming from battery factories, garment factories, steel mill industries and tanneries are highly toxic, causing organic and metal pollution and also lowers the dissolved oxygen in the River water. Thus, it hampers aquatic life and damages the natural ecosystem and water quality [11].

The Rivers Buriganga and Turag are the main receivers of industrial wastewater, flowing around the Dhaka metropolitan, the capital of Bangladesh [12]. Indiscriminate dumping of commercial wastes and discharge of spent liquors containing a variety of industrial chemicals used in textile and leather processing are severely polluting the Rivers. The govt. has been forcing the tanneries to shift to leather industry estate at Savar since 2017 through the High Court verdict. But only a third of the tanneries have shifted yet and discharging of effluent into the Buriganga River has been continued [13]. The scenario of the Turag is not so different. The River was once encircled by farmland where the water was mainly used for fishing and transportation. At present, the people who are working directly or indirectly in the textile and dyeing industries are living in the bank region of the River and significantly dependent on this contaminated water for their household activities [14].

Heavy metals have been considered as an important parameter for systematic assessment of environmental pollution since 1960 [15]. Most heavy metals are harmful to living organisms due to the high persistence accumulation and bioaccumulation [16]. Analysis of the heavy-metal contents in the water and sediment is essential for assessing the overall quality of the aquatic environment [17]. Besides, metal availability in sediments is as important as in fish stocks. Heavy metals in water or soil can transform into the food chain in various ways. Fish living in the water system is a prominent carrier of transfer, accumulation and settlement of heavy metals. Accumulated heavy metals in the heart, liver, gill, bones of fishes besides not only damage the organs but also change the taste and smell of fishes $[18,19]$. The consumption of the fishes may erect health hazards to humans. Usually, heavy metals get adsorbed on the surface of sediment through precipitation at higher $\mathrm{pH}$. The heavy metals absorbed into the sediments are emitted into overlying water if the dissolved oxygen concentration is less than $7 \mathrm{mg} / \mathrm{L}$ [20]. The study on sediment is important as it serves as a habitat for various benthic organisms like mudfish [21].

Heavy-metal concentrations of water vary from season to season due to some physiological characteristics such as temperature, rainfall, runoff, flush out, etc. Usually, heavy rainfall causes leaching, runoff, which ultimately reduced the concentration of heavy metals. A similar variation of heavy-metal accumulation for different seasons has also been reported $[22,23]$. Seasonal variation of trace metals is also very important to include in studies for proper investigation. Irrigation with contaminated water can pose a serious threat to crops grown on the Riverbanks. The Buriganga received wastes from the tannery industries at the Hazaribagh area till 2017. The govt. has undertaken steps to move tanneries to a new tannery estate at Savar for the abatement of pollution that causes health risks of a human living beside the industrial area. Unfortunately, complete relocation has been delayed for more than two years. The govt. has extended the project completion deadline repeatedly [24]. The new Savar tannery zone is located on the banks of the Dhaleshwari River connected to the Buriganga [25]. The centralized effluent treatment plant provided there hasn't been functional fully yet [26]. Very few researchers have conducted assessments after tannery relocation. Now it is necessary to evaluate the benefits of the transfer of tanneries and to ensure the best use of resources to ensure national standards, SDG, etc. At Tongi near Dhaka, 
manufacturers and factories frequently spill toxic waste and fluent to the neighboring Turag River and pollute the water. In Gazipur, the textile and dyeing industries produce wastewater in huge amounts on regular basis. These are being discharged into surrounding channels which finally come into the Turag River [27]. A lot of chemicals like lead, sulfide, grease, hazardous pollutants, oil, color and heavy metals are added to the various unit processes for the manufacture of products. The contamination of this aquatic system poses a dangerous threat to the overall system of the city $[22,28]$.

The study focused on the comparative evaluation of the concentration of heavy metals leached out into nearby Rivers from both textiles and leather industrial areas in Dhaka city. This also studied the seasonal variability of heavy metals in the aquatic environment that involves all Rivers' water, sediment and fish to better determine contamination and health threats correlated with polluted environmental assets.

\section{Method}

\subsection{Description of the study area}

This research consists of two very important Bangladeshi Rivers, namely Buriganga and Turag, adjacent to Bangladesh's capital city, Dhaka. Dhaka metropoli$\tan$ area is about $815.8 \mathrm{~km}^{2}$ located at the midpoint of the country. Dhaka had ranked 7th in the list of most densely populated cities and $21 \mathrm{st}$ in the list of the most polluted city in the world. This city is home to approximately twenty-one million people [29].

The Buriganga ranks among the most polluted Rivers in the world. This River runs past the southwestern fringes of Dhaka town. This River has the highest $18 \mathrm{~m}$ depth with a mean depth of $7.6 \mathrm{~m}$ [25].

The Turag has its origin in the Bangshi River. It is also the upper embranchment of the River Buriganga [30]. Such Rivers were used as appropriate means of disposing of municipal sewage, untreated industrial effluents from rural housing and adjacent industrial belts. The tanneries at the bank of Buriganga have been relocated two years back. There are no statistics on heavymetal pollution following relocation. But many other industries like a tannery, textile, paper and pulps, pesticides distilleries, carbides, pharmaceuticals are operating unhindered on the banks of both the Rivers Buriganga and Turag $[23,30-33]$. Such human and natural activities have resulted in the River habitats becoming degraded, allowing bioaccumulation of heavy metals in comestible fish.

\subsection{Sampling}

The sampling took place from January to February (winter season) in 2018 and from May to June (summer season) in 2019. There were a total of 5 random sampling sites for each River and from each site, there were two samples for one season thereby four samples for the two seasons. Finally, a total of 20 water samples and 20 sediment samples were collected from the selected sites for evaluating the comparative seasonal variation of metal concentration. Unfiltered water samples were taken for total metal analysis from the center of the considered areas of study. The samples then were moved to bottles of $100 \mathrm{~mL}$ of polypropylene, previously washed with acid. Then, $1 \mathrm{~mL}$ of nitric acid (99\%) was added to the polypropylene bottles to gain a $\mathrm{pH}$ of $\approx 0.1$ [34]. Sediment samples were obtained in compliance with standard protocol [35]. All these samples were preserved at $4{ }^{\circ} \mathrm{C}$ till analysis.

Around 12 fish samples were collected from the Bang-

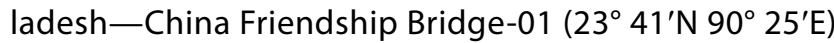
from different stations (Fig. 1) on the Buriganga River near Kamrangir Char and Shaheed Buddhijibi Bridge $\left(23^{\circ} 44^{\prime} \mathrm{N} 90^{\circ} 20^{\prime} \mathrm{E}\right)$ and from the Turag River near Tongi bridge to downstream in between the $23^{\circ} 53^{\prime} \mathrm{N}$ and $90^{\circ} 25^{\prime} \mathrm{E}$ coordinates where fishing activities are high. The three most consumable fish species were selected for the present study namely: Stinging catfish (Heteropneustes fossilis), Spotted-snakehead (Channa punctatus) and Snakehead murrel (Channa striata) (sample specification is given in Table 1). These samples were promptly stored and shipped to the laboratory in air-tight poly bags. Afterward, non-edible pieces were extracted by a previously steam cleaned stainless steel cutter. Muscle tissues which are the key edible component of the fish samples were then rinsed with deionized water. The muscle tissues were then sliced into tiny pieces $(3-5 \mathrm{~cm})$ by a cleaned knife. Then, the possessed samples had been retained at $4{ }^{\circ} \mathrm{C}$ until analysis.

\subsubsection{Sample digestion and metal extraction}

A microwave digestion system was used for sample digestion where $5 \mathrm{ml} 70 \% \mathrm{HNO}_{3}$ acid and $2 \mathrm{ml} \mathrm{30 \%} \mathrm{H}_{2} \mathrm{O}_{2}$ act as a digestion reagent. Measured samples, i.e., $20 \mathrm{ml}$ water, $0.5 \mathrm{~g}$ sediment and $0.3 \mathrm{~g}$ fish, were then put inside Teflon flasks. Then digestion reagent was added up to the mark. Next to digestion, the solution was then filtered using Whatman filter paper 1 . Then the filtrate was stored in $50 \mathrm{ml}$ polypropylene bottles. 


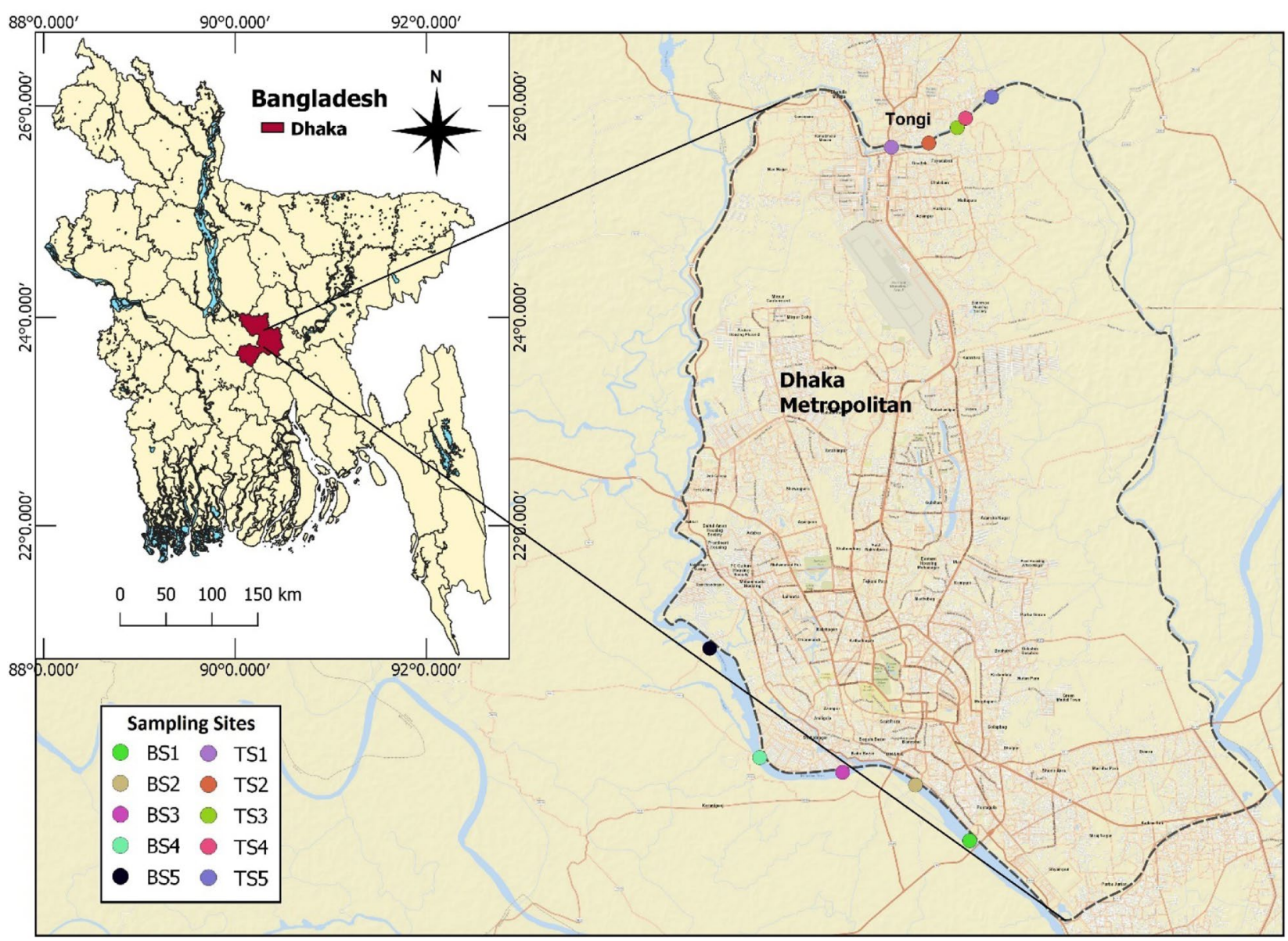

Fig. 1 Study area

Table 1 Basic biological parameters of three selected fish species $[36,37]$

\begin{tabular}{|c|c|c|c|c|c|}
\hline Scientific name & Common name & Local name & Habit & Average TL (cm) & Average BW (g) \\
\hline Heteropneustes fossilis & Stinging catfish & Shing & $\begin{array}{l}\text { Molluscs, cypris, copepod, fish and scales, } \\
\text { larvae of chironomids }\end{array}$ & 17.68 & 14.72 \\
\hline Channa punctatus & Spotted Snake head & Taki & $\begin{array}{l}\text { Carnivorous (small invertebrates and fishes, } \\
\text { debris zooplankton) }\end{array}$ & 13.7 & 9.9 \\
\hline Channa striata & Snakehead murrel & Shol & $\begin{array}{l}\text { Carnivorous (frogs, water bugs and smaller } \\
\text { fish) }\end{array}$ & 60 & 60 \\
\hline
\end{tabular}

\subsubsection{Quality control and assurance programs}

Interior quality was maintained by proper and constant scrutiny of perfect analytical data, records, statistics, method validation, etc. All the reagents (Merck) and standard (commercially available Fluka solution) were analytical grades. The instruments were calibrated before use each time. External quality was maintained by the skilled analyst, proper handling of the sample, reagent and instrument. The precision of the technique/method and mean recoveries of the selected heavy metals are considered $95-97 \%$. For the calibration curve, four dissimilar known concentrations standards were replicated twice while the unknown samples were replicated thrice. Working standards were always newly prepared from the stock solution (1000 ppm, Fluka, Switzerland) by serial dilution. The concentration of heavy metal in the unknown sample was obtained by extrapolation from the calibration curve. Acid blank was run along with the sample regularly which was later subtracted from sample concentration to get the actual concentration of metals in an individual sample. 


\subsubsection{Analytical methods}

Digested samples were analyzed manually by atomic absorption spectroscopy (Model-Perkin Elmer PinAAcle $900 \mathrm{H})$ for $\mathrm{Cr}, \mathrm{Zn}, \mathrm{Fe}, \mathrm{Pb}, \mathrm{Cu}$ and $\mathrm{Ni}$ concentration. Hollow cathode lamps $(\mathrm{HCL})$ were operated according to the recommendation of the manufacturer for $\mathrm{Cr}, \mathrm{Zn}, \mathrm{Fe}, \mathrm{Cu}, \mathrm{Pb}$ and $\mathrm{Ni}$, which ordinarily act as a radiation source for AAS. Acetylene and argon gas with $99.99 \%$ purity acts as fuel for the ignition of the burner.

\subsubsection{Heavy-metal assessment in sediment}

The contamination factor (CF) and the pollution load index (PLI) were calculated to ensure the accumulation of heavy metal in sediment. For this analysis, contaminant indicators were measured by the average shale-value of the earth's crust.

\subsubsection{Contamination factor (CF) and pollution load index} (PLI)

To determine the extent of sediment contamination, an integrated pollution load index (PLI) method of the six metals is measured as per Suresh et al. [38]. The pollution load index (PLI) signifies the number of times by which the trace metal pollution in sediment surpasses the baseline concentration and gives a collective warning of the general heavy-metal toxicity in a specific sample. The emission charge number is calculated as the nth root of the metals contamination factor (CF) multiplications.

$\mathrm{PLI}=\sqrt[n]{\left(C F_{1} \times C F_{2} \times C F_{3} \times \cdots \times C F_{n}\right)}$

Here, the metal contamination factor is the ratio of the concentration of each particular metal to its background values/natural abundance (background value $=$ pre-industrial samples of the study area, Bangladesh)

$C F_{\text {metals }}=\frac{C_{\text {metal }}}{C_{\text {background }}}$

Based on CF values, four grades had been categorized over a duration of time to track the emissions of one metal which are as follows: $[39,40]$.

- Low degree $(\mathrm{CF}<1)$

- Moderate degree $(1 \leq \mathrm{CF}<3)$

- Considerable degree $(3 \leq \mathrm{CF}<6)$

- Very high degree $(\mathrm{CF} \geq 6)$

That's how CF values are being used to evaluate the enhancement in sediments of the given metal throughout the duration of time. Therefore, the PLI value of zero corresponds to the optimal condition while the value of that one implies the existence only of a baseline level of contaminants and a value above the one signifies a degradation of its site and estuary quality [41]. Since the PLI is a result of the contribution of the six metals, it assesses the overall toxicity status of the sample.

\subsection{Health risk assessment}

\subsubsection{Estimated daily intake of metal}

The dietary intake of trace metal has been measured utilizing modest concentrations of fish species. The estimated daily intake (EDI) of metal through eating fish was assessed on the basis of the Islam et al. formula (2014d) [42].

$\mathrm{EDI}=\mathrm{FIR} \times \mathrm{C}$

Here, FIR = food ingestion rate ( $\mathrm{g} /$ person/day) and $C=$ metal concentration in fish ( $\mathrm{mg} / \mathrm{kg}$, wet weight). Fish ingestion or consumption rate for adult residents in Bangladesh had been considered as $0.07184 \mathrm{~kg}, 0.08716 \mathrm{~kg}$ and $0.1274 \mathrm{~kg}$ fresh weight basis for low, medium and high fish consumers. The online database of the Joint FAO/WHO expert panel on food additives unmatched the EDI with the current tentative acceptable daily consumption $[43,44]$.

\subsection{Non-carcinogenic risk assessment}

The ingestion dose is presumed to be equivalent to the amount of adsorbed pollutants. This was also claimed that cooking has no impact on the pollutant [45]. In these analyses, the non-carcinogenic health threats correlated with the local consumer (low, moderate and large consumers of fish) of the contaminated fish species were evaluated on the basis of target hazard quotients (THQs). Calculations were carried out by using standard assumptions for an integrated USEPA risk assessment.

$\mathrm{THQ}=\frac{\mathrm{EFr} \times \mathrm{ED} \times \mathrm{FIR} \times \mathrm{C}}{\mathrm{RfD} \times \mathrm{BW} \times \mathrm{AT}}$

where, exposure frequency, $\mathrm{EFr}=365$ days/year; exposure duration, $E D=70$ years (equivalent to the average life time (USEPA, 1991); oral reference dose $=\mathrm{RfD}(\mathrm{Cr}=1.5, \mathrm{Zn}=0.3$, $\mathrm{Fe}=0.7, \mathrm{~Pb}=0.0035, \mathrm{Cu}=0.04, \mathrm{Ni}=0.02 \mathrm{mg} / \mathrm{kg} /$ day) [46, 47]; average bodyweight, $\mathrm{BW}=$ Adult, $60 \mathrm{~kg}$; averaging time for non-carcinogens, AT $=365$ days/year $\times$ number of exposure years, assuming 70 years. 


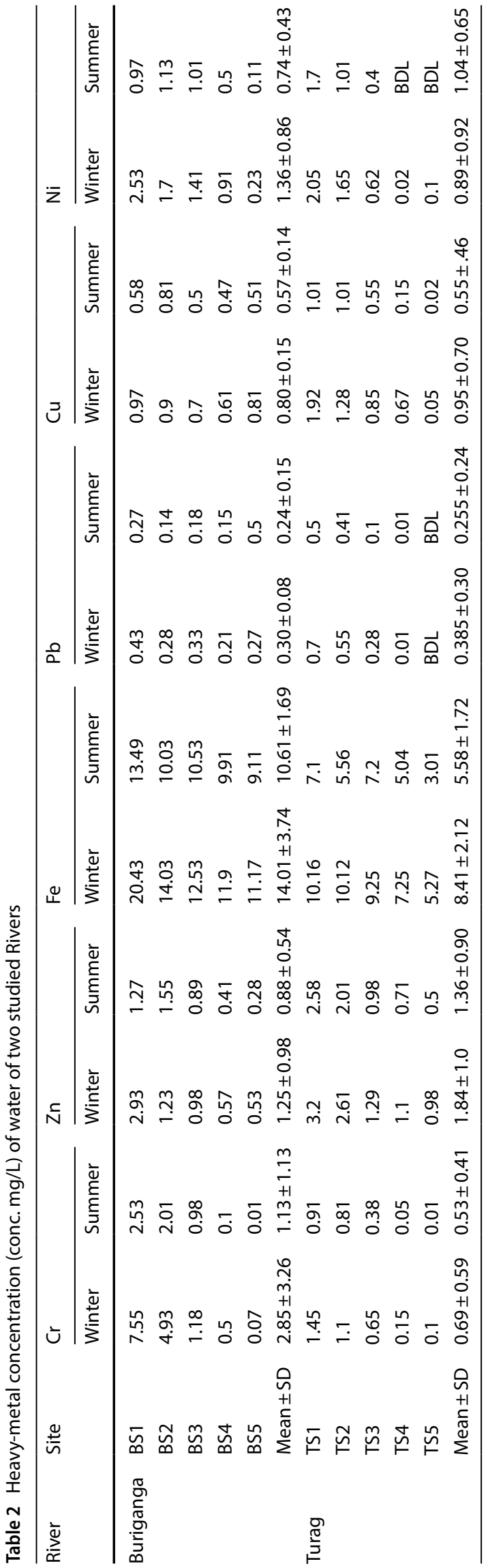

\section{Results and discussion}

\subsection{Assessment of metal concentration of surface water}

The concentration of six heavy metals $(\mathrm{Cr}, \mathrm{Zn}, \mathrm{Fe}$, $\mathrm{Pb}, \mathrm{Cu}$ and $\mathrm{Ni}$ ) over two major seasons (winter and summer) are shown in Table 2. The order of mean concentration of heavy metals in Buriganga water is found to be $\mathrm{Fe}>\mathrm{Cr}>\mathrm{Ni}>\mathrm{Zn}>\mathrm{Cu}>\mathrm{Pb}$ in the winter season whereas during the summer season the order is $\mathrm{Fe}>\mathrm{Cr}>\mathrm{Zn}>\mathrm{Ni}>\mathrm{Cu}>\mathrm{Pb}$. The order of the mean concentration is $\mathrm{Fe}>\mathrm{Zn}>\mathrm{Cu}>\mathrm{Ni}>\mathrm{Cr}>\mathrm{Pb}$ and $\mathrm{Fe}>\mathrm{Zn}>\mathrm{Ni}>\mathrm{Cu}>\mathrm{Cr}>\mathrm{Pb}$ during winter and summer season, respectively, for the Turag River. In winter, the maximum concentration of $\mathrm{Fe}$ is found to be $20.43 \mathrm{mg} / \mathrm{L}$, but in summer the concentration decreased to $13.49 \mathrm{mg} / \mathrm{L}$ for the Buriganga River while the concentrations are noted to be $10.16 \mathrm{mg} / \mathrm{L}$ and $7.1 \mathrm{mg} / \mathrm{L}$, respectively, for Turag River. In the present study, Fe concentration for the Buriganga River is approximately double that of the Turag River and always poses the highest position for both Rivers, both seasons and each site. The highest concentration of Fe for both Rivers is most possibly for natural sources (viz. ore deposition, atmospheric precipitation, degeneration of rocks/mineral by storms, weathering, wind and waves), or by anthropogenic activities (viz. mining, power transmission, carrying industrial emission, electroplating, smelting, sludge dumping, fuel production, dust, severe municipal plus agricultural actions, and wastewater irrigation [4, 31-33]. The mean Fe concentration found in this study is 41 and 23 times higher than that of WHO's standard $(0.30 \mathrm{mg} / \mathrm{L})$. For Buriganga River, the maximum Cr concentration (2nd highest concentration for Buriganga River) is found to be $7.55 \mathrm{mg} / \mathrm{L}$ and $2.53 \mathrm{mg} / \mathrm{L}$ for the winter and summer seasons, respectively. The values are 151 times and 51 times higher than that of WHO standard level for drinking water $(0.05 \mathrm{mg} / \mathrm{L})$. Islam et al. [42] have also reported the $\mathrm{Cr}$ concentration with a value of $2.35 \mathrm{mg} / \mathrm{L}$ for Buriganga. This might be due to the direct discharging of untreated wastewater into the River from tannery industries situated at the west bank of the Buriganga River. Besides, pigment manufacturing, chromium plating and wood preservation may also have a direct role in increasing $\mathrm{Cr}$ concentration $[3,10,28,41,47,49]$. Moreover, Fe and $\mathrm{Cr}$ concentration for Buriganga River poses always higher than that of Turag River due to the tannery industries located at Hazaribagh area and indiscriminate discharging of waste into the River. On the other hand, the Turag River is surrounded by different industrial belts (textile, dyeing industry and fertilizer industry), rural 
housing, agricultural farm and farmland, which ultimately increase the amount of $\mathrm{Zn}$ and $\mathrm{Cu}$ concentration in the Turag River [25-27]. In the Turag River, the 2nd highest concentration is found for $\mathrm{Zn}$ with a maximum concentration of $3.2 \mathrm{mg} / \mathrm{L}$ and $2.58 \mathrm{mg} / \mathrm{L}$ during winter and summer, respectively. However, the chromium concentrations (mean conc. $0.69 \mathrm{mg} / \mathrm{L}$ ) in the Turag River water are much lower than that of Buriganga River water (mean conc. $2.85 \mathrm{mg} / \mathrm{L}$ ). For the Buriganga, the average concentration of $\mathrm{Ni}(1.36 \mathrm{mg} / \mathrm{L})$ is found to be higher than that of $\mathrm{Zn}(1.25 \mathrm{mg} / \mathrm{L})$ in the winter. Whereas, for the Turag River, the average concentration of $\mathrm{Ni}(0.89 \mathrm{mg} / \mathrm{L})$ is found to be lower than that of $\mathrm{Zn}(1.84 \mathrm{mg} / \mathrm{L})$. In the summer season, the measured average concentrations are noted to be decreased to $0.88 \mathrm{mg} / \mathrm{L}(\mathrm{Zn})$ and $0.74(\mathrm{Ni})$ for Buriganga River and $1.36 \mathrm{mg} / \mathrm{L}(\mathrm{Zn})$ and $1.04 \mathrm{mg} / \mathrm{L}$ (Ni) for Turag River. The concentrations of $\mathrm{Cu}$ and $\mathrm{Pb}$ are very low as compared to the other considered metals, for both Buriganga and Turag River. Mean concentrations for $\mathrm{Cu}$ and $\mathrm{Pb}$ are found to be $0.80 \mathrm{mg} / \mathrm{L}(0.57 \mathrm{mg} / \mathrm{L})$ and $0.30 \mathrm{mg} / \mathrm{L}(0.24 \mathrm{mg} / \mathrm{L})$, respectively, in winter (summer) for the Buriganga River. For Turag River, the concentration values of $\mathrm{Cu}$ and $\mathrm{Pd}$ are $0.95 \mathrm{mg} / \mathrm{L}(0.55 \mathrm{mg} / \mathrm{L})$ and $0.385 \mathrm{mg} / \mathrm{L}(0.255 \mathrm{mg} / \mathrm{L})$ in winter (summer), respectively. All the values are higher than the toxicity reference values (TRV) proposed by USEPA (1999) [46] for drinking water. The higher $\mathrm{Pb}$ concentration in the Turag River might be due to the discharging of waste from the nearby battery industry, textile industries, lead-based paints from the dyeing industry or PVC containing children's toys [50]. Whereas, higher Cu concentration in the Turag River perhaps due to the dissolution, leaching, sorption, sewage and runoff of the domestic farm $[22,23]$.

The concentration of metals in the Buriganga and Turag River water varies seasonally; might be associated with some complex phenomena like lack of rainfall in winter, which might allow metal precipitation, re-suspension and deposition [31, 47]. The concentrations are found higher in the winter season than that of the summer season. In the summer, the minimum value of heavy metals may be attributed to either the dilution impact of River water. Besides, Bangladesh is an agricultural-based country and most of the agricultural activities are conducting in around the winter season. Thus, the agricultural waste and sewage from the farmland might have a direct role for the higher concentration of $\mathrm{Fe}, \mathrm{Zn}, \mathrm{Cu}$ and $\mathrm{Ni}$ in the winter season [40, 48]. Moreover, increased anthropogenic activities like brick production, excavation, power production, carrying industrial emission, electroplating, smelting, sludge dumping, fuel production etc. also enhance the concentration of heavy metal in winter [31-33]. The concentration values showing a decreasing pattern from the first sampling site to the last (BS1 to BS5 and TS1 to TS5) which might be attributed to the increasing distance of the sampling site from industrial discharge and/or domestic sewage discharge point. Concentration levels of most the metals, in general, surpassed several well-recognized quality values and in line with certain previous research (Table 3) [46, 49, 51-55].

\subsection{Assessment of Sediment concentrations in River}

The concentration of trace metals in the sediment of Buriganga and Turag River is presented in Table 4. However, the heavy-metal accumulation is higher in site BS1 and TS1 for the Buriganga River and Turag River, respectively. The lowering of metal concentrations in the other sites is due to their downstream location of the River with extensive discharging of urban waste $[23,53]$. The concentrations are also higher in winter compared to the summer season due to the low water flow in the winter season accompanied by the increased unsustainable agricultural practices and human activity compared to the summer season [31-33].
Table 3 Comparison of metals in water $(\mathrm{mg} / \mathrm{L})$ with different international guidelines and other studies in the world

\begin{tabular}{llllllll}
\hline River, location & $\mathrm{Cr}$ & $\mathrm{Zn}$ & $\mathrm{Fe}$ & $\mathrm{Pb}$ & $\mathrm{Cu}$ & $\mathrm{Ni}$ & Reference \\
\hline Buriganga (Bangladesh) & 1.99 & 1.06 & 12.31 & 0.28 & 0.69 & 1.05 & Present study \\
Turag (Bangladesh) & 0.61 & 1.60 & 7.0 & 0.32 & 0.75 & 0.96 & Present study \\
Korotoa (Bangladesh) & 0.078 & - & - & 0.031 & 0.067 & 0.0355 & Islam et al. (2015) [49] \\
River Ganges (India) & 0.012 & 0.072 & - & 0.043 & 0.017 & - & Gupta et al. (2009) [51] \\
Bangshi River (Bangladesh) & 0.114 & 3.012 & & 0.088 & 0.890 & 0.026 & Rahman et al. (2014) [52] \\
Okumeshi River (Nigeria) & 0.09 & - & - & 0.01 & - & 0.27 & Raphael et al. (2011) [53] \\
DWSB & & & & & & &
\end{tabular}

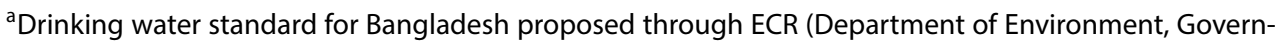
ment of the People's Republic of Bangladesh, DoE, 1997)

${ }^{\text {b} T R V ~(t o x i c i t y ~ r e f e r e n c e ~ v a l u e) ~ f o r ~ f r e s h ~ w a t e r ~ p r o p o s e d ~ b y ~ U S E P A ~(1999) ~}$ 


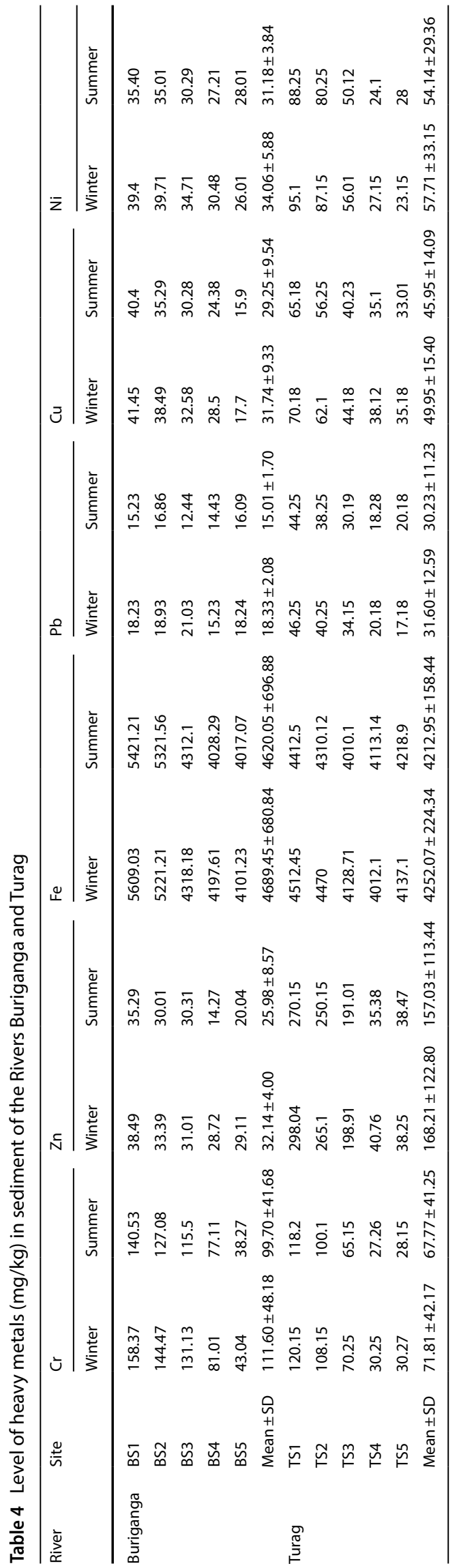

Later these heavy metals easily accumulate/absorbed on sediment by precipitation at higher $\mathrm{pH}[4,20,23,50]$. The decreasing trend of mean concentration in sediments is $\mathrm{Fe}>\mathrm{Cr}>\mathrm{Ni}>\mathrm{Cu}>\mathrm{Zn}>\mathrm{Pb}$ for the Buriganga River and $\mathrm{Fe}>\mathrm{Zn}>\mathrm{Cr}>\mathrm{Ni}>\mathrm{Cu}>\mathrm{Pb}$ for the Turag River. However, the two hierarchies for the sediment have a close match with the mean concentration hierarchy for most of the selected heavy metals in the water and revealed a close relationship for the metal concentration in water and sediment due to the surrounding environment including all biotic and abiotic factors. If anyhow the concentration of toxic metal concentration increased in water, it not only confined in water system rather than destroy the entire food chain [54]. The Fe concentration in the sediment is found to be $5609.03-4101.23 \mathrm{mg} / \mathrm{kg}(5421.21-4017.07 \mathrm{mg} / \mathrm{kg})$ in winter (summer) collected from the Buriganga River and $4512.45-4012.1 \mathrm{mg} / \mathrm{kg}(4412.5-4010.1 \mathrm{mg} / \mathrm{kg})$ in winter (summer) collected from the Turag River. The maximum chromium concentration is noted to be $158.37 \mathrm{mg} / \mathrm{kg}$ $(140.53 \mathrm{mg} / \mathrm{kg}$ ) in winter (summer) season which is the 2nd highest metal concentration for Buriganga River while for Turag River it is $3 \mathrm{rd}$ highest metal concentration with a value of $120.15-30.27$ (118.2-28.15) $\mathrm{mg} / \mathrm{kg}$ in winter (summer). In sediment of both Rivers, chromium concentration is higher than that of $\mathrm{Ni}, \mathrm{Cu}$ and $\mathrm{Pb}$, even higher than the average shale value, which might be due to the direct discharging of untreated wastes from tanneries, chemical industries, dye industry and textile industries on the bank of the Rivers $[4,56,57]$. Maximum Ni concentration is found to have the value of $39.71 \mathrm{mg} / \mathrm{kg}(35.4 \mathrm{mg} / \mathrm{kg})$ in winter (summer) while for the Turag River, the maximum concentration is $95.1 \mathrm{mg} / \mathrm{kg}(88.25 \mathrm{mg} / \mathrm{kg})$ in winter (summer) which is higher than that of Buriganga River. The average value of $\mathrm{Cu}$ in the sediment of the Buriganga River is found to be $31.74 \mathrm{mg} / \mathrm{kg}(29.25 \mathrm{mg} / \mathrm{kg})$ in winter (summer) and in the sediment of Turag River, the value is $49.95 \mathrm{mg} / \mathrm{kg}(45.95 \mathrm{mg} / \mathrm{kg}$ ) in winter (summer) season. The $\mathrm{Cu}$ concentration is higher in Turag River compared to Buriganga River due to the urban and industrial waste disposal into the River, leaching, runoff from surrounding unsustainable farmland (where most of the farmers injudiciously applied fertilizers and pesticides) that might have a direct role in increasing $\mathrm{Cu}$ concentration $[56,57]$. The mean concentration of $\mathrm{Pb}$ in the sediment of the Buriganga River is $18.33 \mathrm{mg} / \mathrm{kg}(15.01 \mathrm{mg} / \mathrm{kg})$ in winter (summer) while it is $31.60 \mathrm{mg} / \mathrm{kg}(30.23 \mathrm{mg} / \mathrm{kg})$ in winter (summer) season for the Turag River. The $\mathrm{Pb}$ concentration is low in the sediment of the Buriganga River than that of the Turag River. This difference in the concentrations might be due to the influence of contaminants from the point and non-point water pollution sources for instance: battery industry, leaded gasoline, municipal runoffs, industrial waste disposal or effluent discharge, chemical 
Table 5 Comparison of metals in sediment $(\mathrm{mg} / \mathrm{kg})$ with different international guidelines and other studies in the world

\begin{tabular}{llllllll}
\hline River, location & $\mathrm{Cr}$ & $\mathrm{Ni}$ & $\mathrm{Cu}$ & $\mathrm{Pb}$ & $\mathrm{Fe}$ & $\mathrm{Zn}$ & Reference \\
\hline Buriganga (Bangladesh) & 106 & 33 & 31 & 17 & 4655 & 29 & Present study \\
Turag (Bangladesh) & 70 & 56 & 48 & 31 & 4233 & 163 & Present study \\
Korotoa (Bangladesh) & 109 & 95 & 76 & 58 & - & - & Islam et al. (2015) [49] \\
Padma River (Bangladesh) & 97 & 28 & 25 & 17 & 4.88 (\%) & 76 & Datta and Subramanian (1998) [58] \\
Jamuna River (Bangladesh) & 110 & 33 & 28 & 19 & 4.22 (\%) & 83 & Datta and Subramanian (1998) [58] \\
Bangshi River (Bangladesh) & 98 & 28 & 31 & 60 & - & 117.15 & Rahman et al. (2014) [51] \\
Okumeshi River (Nigeria) & 0.87 & 1.21 & $\mathrm{NA}$ & 0.45 & - & - & Raphael et al. (2011) [52] \\
ASV & 90 & 68 & 45 & 20 & 47,200 & 95 & Turekian and Wedepohl (1961) [39] \\
TRV & 26 & 16 & & 31 & 110 & 16 & USEPA (1999) [46] \\
LEL & 26 & 16 & 16 & 31 & $2 \%$ & 120 & Persuad et al. (1993) [59] \\
SEL & 110 & 75 & 110 & 250 & $4 \%$ & 820 & Persuad et al. (1993) [59] \\
\hline
\end{tabular}

$A S V \rightarrow$ average shale value, $T R V \rightarrow$ toxicity reference value, $L E L \rightarrow$ low effect level, $S E L \rightarrow$ severe effect level, $N A \rightarrow$ not available

plant, steelworks, atmospheric deposition, etc. [23, 57-62]. Though the mean concentration of the $\mathrm{Pb}$ found in the sediment of Buriganga River is below the average shale value (ASV) $(20 \mathrm{mg} / \mathrm{kg})$ but it is around $45 \%$ higher than the ASV for the Turag River. The average concentrations of most of the metals are higher than some well-recognized standard values that indicate the hazardous sediment pollution (Tables 4 and 5) with direct health risk for present and upcoming generation. The obtained values of different metal concentrations are given in Table 4; the average of the values is presented in Table 5 along with other reported values $[39,46,49,52,53,59]$.

\subsection{Contamination Factor (CF) and Pollution Load Index (PLI)}

The contamination factors (CF) of each metal have been calculated using the average shale value of the earth's crust $(\mathrm{Cr}=90, \mathrm{Ni}=68, \mathrm{Cu}=45, \mathrm{~Pb}=20, \mathrm{Fe}=47,200, \mathrm{Zn}=95)$ [39] and further calculated the pollution load index (PLI) for each sampling site. The CF values are shown in Table 6 . For the Buriganga River, the values of contamination factor (CF) for all metals show a low degree of contamination $(C F<1)$ except for chromium (CF $>1)$. The decreasing order of $C F$ values for sediment samples collected from the Buriganga River is $\mathrm{Cr}>\mathrm{Pb}>\mathrm{Cu}>\mathrm{Ni}>\mathrm{Zn}>\mathrm{Fe}$. As seen in Table 6, the maximum value of $C F$ is 1.75 for $C r$ and the lowest is 0.09 for Fe in the winter season. In the summer season, the maximum value of $C F$ is also for $\mathrm{Cr}$ (1.56) and the lowest value is for $\mathrm{Fe}$ (0.085). The highest value of CF indicates that chromium is mostly responsible for the contamination of sediment. It is a matter of great concern because $\mathrm{Cr}$ is an extremely hazardous environmental and industrial pollutants classified as a group-1 human carcinogen. Excess and chronic $\mathrm{Cr}$ exposure has a carcinogenic effect damaging DNA, circulatory system, digestive system and nervous system $[31,61]$. The CF of the sediment collected from the Turag River indicates a low degree of $\mathrm{Cr}$, Fe and $\mathrm{Ni}$ contamination $(\mathrm{CF}<1)$ and moderate contamination of $\mathrm{Zn}$, $\mathrm{Pb}$ and $\mathrm{Cu}$ with $\mathrm{CF}$ values greater than 1. The decreasing

Table 6 Contamination factor (CF) of heavy metals in sediment of two studied Rivers

\begin{tabular}{|c|c|c|c|c|c|c|c|c|c|c|c|c|c|}
\hline \multirow[t]{2}{*}{ River } & \multirow[t]{2}{*}{ Site } & \multicolumn{2}{|l|}{$\mathrm{Cr}$} & \multicolumn{2}{|l|}{$\mathrm{Zn}$} & \multicolumn{2}{|l|}{$\mathrm{Fe}$} & \multicolumn{2}{|l|}{$\mathrm{Pb}$} & \multicolumn{2}{|l|}{$\mathrm{Cu}$} & \multicolumn{2}{|l|}{$\mathrm{Ni}$} \\
\hline & & Winter & Summer & Winter & Summer & Winter & Summer & Winter & Summer & Winter & Summer & Winter & Summer \\
\hline \multirow[t]{5}{*}{ Buriganga } & BS1 & 1.76 & 1.56 & 0.41 & 0.37 & 0.12 & 0.11 & 0.91 & 0.76 & 0.92 & 0.90 & 0.58 & 0.52 \\
\hline & BS2 & 1.61 & 1.41 & 0.35 & 0.32 & 0.11 & 0.11 & 0.95 & 0.84 & 0.86 & 0.78 & 0.58 & 0.51 \\
\hline & BS3 & 1.46 & 1.28 & 0.33 & 0.32 & 0.09 & 0.09 & 1.05 & 0.62 & 0.72 & 0.67 & 0.51 & 0.45 \\
\hline & BS4 & 0.90 & 0.86 & 0.30 & 0.15 & 0.09 & 0.09 & 0.76 & 0.72 & 0.63 & 0.54 & 0.45 & 0.40 \\
\hline & BS5 & 0.48 & 0.43 & 0.31 & 0.21 & 0.09 & 0.09 & 0.91 & 0.80 & 0.39 & 0.35 & 0.38 & 0.41 \\
\hline \multirow[t]{5}{*}{ Turag } & TS1 & 1.34 & 1.31 & 3.14 & 2.84 & 0.10 & 0.09 & 2.31 & 2.21 & 1.56 & 1.45 & 1.00 & 0.93 \\
\hline & TS2 & 1.20 & 1.11 & 2.79 & 2.63 & 0.09 & 0.09 & 2.01 & 1.91 & 1.38 & 1.25 & 0.92 & 0.84 \\
\hline & TS3 & 0.78 & 0.72 & 2.09 & 2.01 & 0.09 & 0.08 & 1.71 & 1.51 & 0.98 & 0.89 & 0.59 & 0.53 \\
\hline & TS4 & 0.34 & 0.30 & 0.43 & 0.37 & 0.09 & 0.09 & 1.01 & 0.91 & 0.85 & 0.78 & 0.29 & 0.25 \\
\hline & TS5 & 0.34 & 0.31 & 0.40 & 0.40 & 0.09 & 0.09 & 0.86 & 1.01 & 0.78 & 0.73 & 0.24 & 0.29 \\
\hline
\end{tabular}




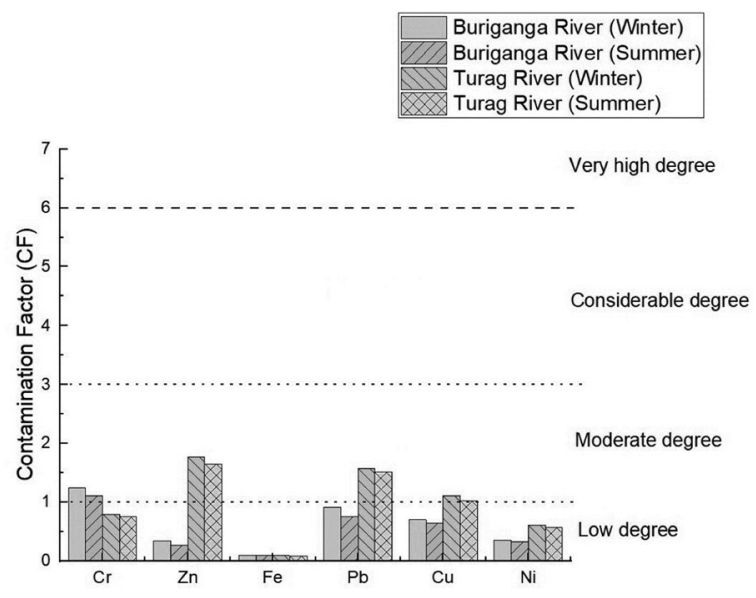

Fig. 2 Contamination factor (CF) of heavy metals in sediment of two studied Rivers

order of $C F$ values for sediment samples collected from the Turag River is $\mathrm{Zn}>\mathrm{Pb}>\mathrm{Cu}>\mathrm{Cr}>\mathrm{Ni}>\mathrm{Fe}$. The $\mathrm{CF}$ value of $Z n$ (3.14) suggests that attention should be paid to the contamination level. Although $\mathrm{Zn}$ is an essential micronutrient for most living beings (acts as a cofactor for $\sim 300$ enzymes) but toxicity may arise due to excessive intake which results in electrolyte imbalance, vomiting, anemia and tiredness $[62,63]$. The $\mathrm{CF}$ values of $\mathrm{Pb}, \mathrm{Cu}$ and $\mathrm{Cr}$ for the first sampling site (TS1) in winter are 2.31, 1.56 and 1.34 , respectively, indicating moderate contamination. The highest value of CF is found for $\mathrm{Zn}$ (2.84) and the lowest value is for $\mathrm{Fe}(0.08)$ in the summer season, indicating the dominant role of $\mathrm{Zn}$ in the sediment contamination of TS1 along with the significant contribution from the $\mathrm{Cr}, \mathrm{Pb}$ and $\mathrm{Cu}$. The mean $\mathrm{CF}$ values of $\mathrm{Cr}, \mathrm{Zn}, \mathrm{Fe}, \mathrm{Pb}, \mathrm{Cu}$ and $\mathrm{Ni}$ are 0.80 , $1.77,0.09,1.58,1.11$ and 0.61 , respectively, during the winter season, whereas it is $0.75,1.65,0.09,1.51,1.02$ and 0.57 , respectively for the summer season (Fig. 2). It should be noted that Fe despite being an essential heavy metal for the proper function of body organs such as hemoglobin synthesis but excess amounts have different disorders like hereditary hemochromatosis, cancer, arthritis, liver damage, heart failure and diabetes $[4,63]$. In contrast, $\mathrm{Ni}, \mathrm{Cu}$ and $\mathrm{Zn}$ are three vital micronutrients for plant and human nutrition. $\mathrm{Ni}$ is a crucial constituent for the urease enzyme, but more than $50 \mathrm{mg} / \mathrm{kg}$ dry weight (DW) in plants vegetative stage may suffer from toxicity symptoms like wilting. While severe toxicity may destroy the respiratory tract and immune system and acute toxicity may cause death in humans [4]. Cu is an important constituent for normal physiological functions such as hemoglobin synthesis, catalysts in metabolic reaction [64]. But extreme and prolonged exposure to $\mathrm{Cu}$ has been linked to cellular damage in humans $[65,66]$. CF values for the selected heavy metal differ largely for the two Rivers due to their different

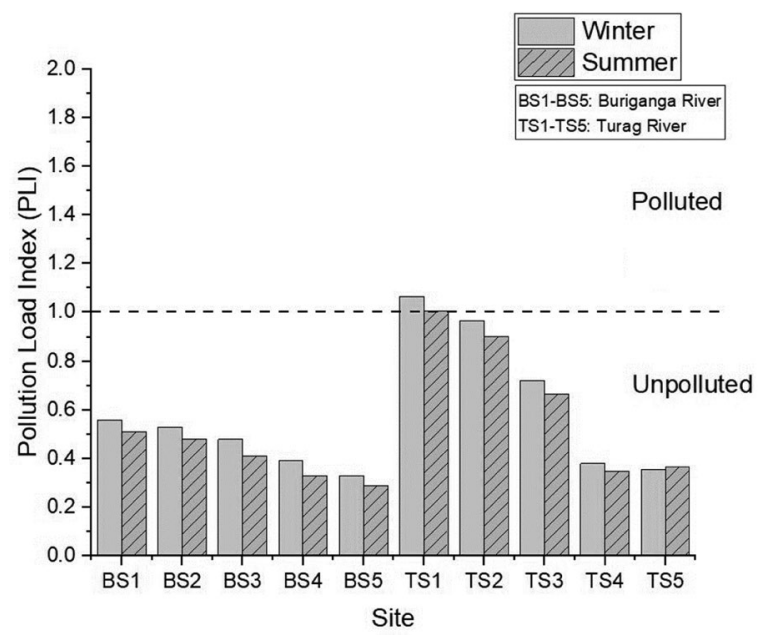

Fig. 3 Pollution load index (PLI) of heavy metals in sediment of two studied Rivers

geographical position which facilitates easy enrichment of different types of untreated waste from the surroundings $[56,57,61]$. However, present CF values for Buriganga and Turag River have close agreement with Ahmad et al. [31] where they elucidated the average of $C F$ value as follows: $\mathrm{Cr}=0.67-1.59, \mathrm{Ni}=0.23-0.92, \mathrm{Cu}=0.41-1.54$, $\mathrm{Zn}=0.75-1.51$ and $\mathrm{Pb}=0.78-1.82$, Weihe River, China.

The pollution load index (PLI) is illustrated in Fig. 3. In this study, PLI values for all the sites of the Buriganga River are below 1 indicating the baseline pollution level while for the first site of Turag River the values are slightly greater than 1 during both seasons. PLI is an important helping tool to assess the quality of the environment and also assist the policymakers in making environment protective policies. During the winter season, the values of $\mathrm{PLI}$ are in the range of 0.56 to 0.33 for Buriganga and 1.06 to 0.35 for Turag which are 0.51 to 0.29 and 1.006 to 0.35 for Buriganga and Turag, respectively, in the summer season. The maximum value of $\mathrm{PLI}$ is $0.56(0.51)$ during winter (summer) for the site BS1 of the Buriganga River. On the other hand, the maximum value of PLI is 1.06 (1.006) during winter (summer) for the site TS1 of the Turag River. The higher values of $\mathrm{PLI}$ indicate a higher pollution load of the Turag River compared to the Buriganga River.

\subsection{Metal concentrations in fish species of studied Rivers}

When toxicants enter the bloodstream, different heavy metals reach and easily gather in different inner organs (e.g., gill, liver, stomach, intestine, kidney, gonad and muscles) of fish. Various concentrations of contaminants are prevalent in the different organs of fish owing to the extent level of affinity among them. Different 
Table 7 Heavy-metal concentration of three commonly consumed fish species of the Buriganga and Turag River

\begin{tabular}{|c|c|c|c|c|c|c|c|c|c|}
\hline \multirow[t]{2}{*}{ Metal } & \multirow[t]{2}{*}{ Season } & \multicolumn{3}{|l|}{ Buriganga } & \multicolumn{3}{|l|}{ Turag } & \multirow[t]{2}{*}{ *FSG } & \multirow[t]{2}{*}{ References } \\
\hline & & $\begin{array}{l}\text { Het- } \\
\text { eropneustes } \\
\text { fossilis }\end{array}$ & Channa punctatus & Channastriata & $\begin{array}{l}\text { Het- } \\
\text { eropneustes } \\
\text { fossilis }\end{array}$ & $\begin{array}{l}\text { Channa } \\
\text { punctatus }\end{array}$ & Channa striata & & \\
\hline \multirow[t]{2}{*}{$\mathrm{Cr}$} & Winter & 187.07 & 144.38 & 113.07 & 70.18 & 43.29 & 60.9 & \multirow[t]{2}{*}{$12-13$} & \multirow[t]{2}{*}{ USFDA (1993) [73] } \\
\hline & Summer & 121.77 & 88.09 & 67.01 & 45.01 & 20.18 & 49.2 & & \\
\hline \multirow[t]{2}{*}{$\mathrm{Zn}$} & Winter & 35.12 & 15.03 & 21.07 & 68.25 & 58.1 & 52.18 & \multirow[t]{2}{*}{30} & \multirow[t]{4}{*}{ FAO (1983) [72] } \\
\hline & Summer & 12.07 & 11.08 & 14.01 & 38.1 & 29.13 & 30.25 & & \\
\hline \multirow[t]{2}{*}{$\mathrm{Fe}$} & Winter & 39.07 & 29.76 & 25.07 & 45.1 & 34.25 & 33.26 & \multirow[t]{2}{*}{ NA } & \\
\hline & Summer & 27.01 & 20.11 & 19.66 & 22.3 & 25.01 & 25.25 & & \\
\hline \multirow[t]{2}{*}{$\mathrm{Pb}$} & Winter & 5.07 & 3.24 & 1.28 & 6.22 & 9.15 & 10.18 & \multirow[t]{2}{*}{2.0} & \multirow[t]{2}{*}{ WHO (1995) [74] } \\
\hline & Summer & 4.01 & 1.32 & 1.2 & 4.01 & 5.28 & 6.24 & & \\
\hline \multirow[t]{2}{*}{$\mathrm{Cu}$} & Winter & 3.51 & 3.21 & 3.07 & 6.03 & 9.2 & 10.4 & \multirow[t]{2}{*}{30} & \multirow[t]{2}{*}{ WHO (1995) [74] } \\
\hline & Summer & 2.07 & 2.51 & 2.5 & 5.03 & 6.01 & 7.25 & & \\
\hline \multirow[t]{2}{*}{$\mathrm{Ni}$} & Winter & 3.01 & 0.78 & 1.51 & 12.18 & 11.28 & 10.2 & \multirow[t]{2}{*}{80} & \multirow[t]{2}{*}{ USFDA(1993) [73] } \\
\hline & Summer & 2.21 & 0.07 & 1.02 & 8.23 & 6.01 & 6.27 & & \\
\hline
\end{tabular}

${ }^{*}$ Food safety guidelines, $N A \rightarrow$ not available

concentrations of pollutants in different fish organs seem to be pervasive because of multiple stages of affinity among them $[60,61]$. Heavy-metal concentration in the studied fishes collected from the two studied Rivers is presented in Table 7. Throughout all the fish species, the highest concentration is found for $\mathrm{Cr}$. The decreasing trend of metal concentration in the fish muscles is $\mathrm{Cr}>\mathrm{Zn}>\mathrm{Fe}>\mathrm{Ni}>\mathrm{Pb}>\mathrm{Cu}$ for Heteropneustes fossilis, $\mathrm{Cr}>\mathrm{Zn}>\mathrm{Fe}>\mathrm{Cu}>\mathrm{Pb}>\mathrm{Ni}$ for Channa punctatus and $\mathrm{Cr}>\mathrm{Zn}>\mathrm{Fe}>\mathrm{Cu}>\mathrm{Ni}>\mathrm{Pb}$ for Channa striata. Among the three studied species, the heavy-metal concentrations can be ranked as follows: Heteropneustes fossilis > Channa punctatus $>$ Channa striata. This type of hierarchy is most possibly due to their feeding habit. Among the studied species, Channa punctatus and Channa striata are carnivorous while Heteropneustes fossilis is omnivorous that may have a higher capacity of metal accumulation [36, 37]. Different researchers have studied the variation of heavy-metal accumulation in different parts (e.g., liver, kidneys, gills, muscle, etc.) of fish $[18,19]$ which revealed that the edible portion contains less heavy metal compared to the inedible portion [61]. However, people generally consume only the muscle portion of fish in Bangladesh. Thus, only the edible portions of the fish muscles are considered in this study. The hierarchy of heavy-metal concentrations found in the fish species is $\mathrm{Cr}>\mathrm{Fe}>\mathrm{Zn}>\mathrm{Pb}>\mathrm{Cu}>\mathrm{Cd}$ which is in good agreement with the prior report [67]. It had been reported that the concentration of various metals in fish usually follows: $\mathrm{Cr}>\mathrm{Fe}>\mathrm{Zn}>\mathrm{Pb}>\mathrm{Cu}>\mathrm{Cd}$ [67] which is in agreement with the findings of the present study. A significant variation of the concentration is also observed in two seasons which is influenced by the growth cycle, age (size) and feeding habits of the species $[68,69]$ along with the variation of local pollution [70].

The highest concentration of $\mathrm{Cr}(187.07 \mathrm{mg} / \mathrm{kg})$ is found in Heteropneustes fossilis in the winter season collected from the Buriganga River that is decreased to $121.77 \mathrm{mg} /$ $\mathrm{Kg}$ during the summer. The high value of $\mathrm{Cr}$ in this species might be due to the discharging of chromium tanning liquor from adjacent tannery industries [23]. Previous studies have reported that the substances with chromium (VI) enhance the risk of developing lung cancer [71]. Fish well-being may also be affected by $\mathrm{Cr}$ exposure. The highest concentration of $\mathrm{Zn}$ is found in Heteropneustes fossilis $(68.25 \mathrm{mg} / \mathrm{kg})$ collected from the Turag River in the winter season. But during the summer, Spotted snakehead fish shown the lowest concentration of $\mathrm{Zn}(11.08 \mathrm{mg} / \mathrm{kg})$.

The mean concentration of both seasons for $\mathrm{Fe}$ is found to be $33.04 \mathrm{mg} / \mathrm{kg}, 24.935 \mathrm{mg} / \mathrm{kg}$ and $22.365 \mathrm{mg} / \mathrm{kg}$ for Heteropneustes fossilis, Channa punctatus fish and Channa striata, respectively, collected from the Buriganga River while it is $33.7 \mathrm{mg} / \mathrm{kg}, 29.63 \mathrm{mg} / \mathrm{kg}$ and $29.255 \mathrm{mg} / \mathrm{kg}$, respectively, collected from the Turag River. The mean concentrations of $\mathrm{Cu}$ are in the range of 3.51 to $3.07 \mathrm{mg} / \mathrm{kg}$ for the studied fish species collected from the Buriganga River which is almost half of that of the Turag River. The mean concentrations of $\mathrm{Pb}$ are low for the studied species with a maximum concentration of $\mathrm{Pb}(10.18 \mathrm{mg} / \mathrm{kg})$ found in Channa striata collected from the Turag River during the winter. The minimum concentration of $\mathrm{Pb}$ is found in Channa striata collected from the Buriganga River during the summer. The Ni concentration is much higher in the fishes collected in the Turag River compared to that of the 


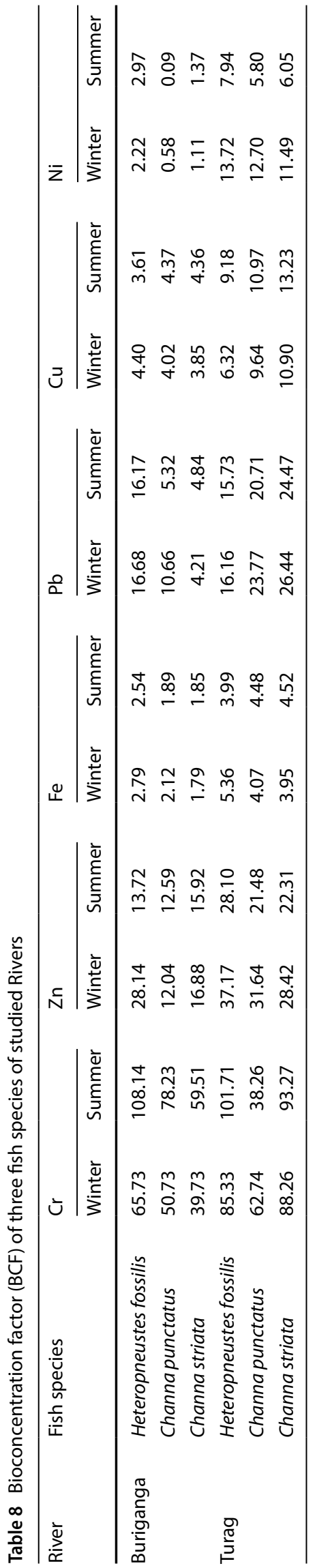

Buriganga River. The highest mean concentration of both seasons for $\mathrm{Ni}$ is found in Heteropneustes fossilis collected from the Turag River. It's a matter of great concern that the concentration levels for most of the metals surpassed several well-recognized permissible values (Table 7) [72-74].

\subsection{Bioconcentration Factor}

The bioconcentration factor (BCF) was used to evaluate the aquatic organism's capacity to accumulate chemical substances from water [75]. BCF values for the studied fish species of both Rivers are presented in Table 8. The BCF value greater than 1 indicates that the fish has the potential to accumulate metals from the water. But immediate action needs to be taken when the value of BCF is greater than 100. Table 8 shows that only Heteropneustes fossilis collected from both Rivers [Buriganga (108.14) and Turag (101.71)] have BCF values greater than 100 for $\mathrm{Cr}$ during the summer. The BCF value of the same species also has higher values compared to others for both Rivers. However, the values exhibit inconsistency throughout the considered species and Rivers might be due to the wide distribution and migration of the fishes throughout the River. Furthermore, the variation of BCF values also indicate the difference in the response and behavior of Heteropneustes fossilis toward different trace metals $[76,77]$.

\subsection{Health risk assessment}

Around 20 million people live in Dhaka city and a large number of these people consume different types of fish species. The studied fish species are commonly consumed among them; consequently, the question of health risk associated with the consumption of these fishes collected from Buriganga and Turag River should have arisen. The health risk can be assessed by calculating the estimated daily intake (EDI) of metal and target hazard quotients (THQ). The obtained values of EDI and THQ from studied fish species are presented in Table 9.

The EDI values of $\mathrm{Cr}, \mathrm{Zn}$ and Fe are high for both Rivers. The obtained EDI values for $\mathrm{Cr}$ [for both Rivers] are higher than the maximum tolerable daily dietary intake limit (MTDI). The MTDI values for Fe and $Z n$ are not available. The EDI for $\mathrm{Pb}$ is lower than the MTDI only for low fish consumers but higher than the MTDI for medium and high fish consumers collected from the Buriganga River. The EDI values for $\mathrm{Cr}, \mathrm{Pb}$ and $\mathrm{Ni}$ are higher than the MTDI in the case of the Turag River. The EDI values for $\mathrm{Cu}$ [both Rivers] are lower than the MTDI.

Target hazard quotients (THQs) of heavy metals in the studied fish species are presented in Table 9. The THQ of the metals as a result of fish consumption can be ranked as follows: $\mathrm{Pb}>\mathrm{Cr}>\mathrm{Ni}>\mathrm{Cu}>\mathrm{Zn}>\mathrm{Fe}$ for the Buriganga River 
Table 9 Estimated daily intake (EDI), non-carcinogenic risk of metals from fish consumption

\begin{tabular}{|c|c|c|c|c|c|c|c|c|c|}
\hline \multirow[t]{2}{*}{ River } & \multirow[t]{2}{*}{ Metal } & \multirow[t]{2}{*}{ Mean conc } & \multicolumn{3}{|c|}{ Estimated Daily Intake of heavy metal } & \multirow[t]{2}{*}{$\mathrm{MTDI}^{\mathrm{a}}(\mathrm{mg} /$ day $)$} & \multicolumn{3}{|c|}{ Target Hazard Quotient (THQ) } \\
\hline & & & $\begin{array}{l}\text { Low Fish } \\
\text { Consumer }\end{array}$ & $\begin{array}{l}\text { Medium Fish } \\
\text { Consumer }\end{array}$ & $\begin{array}{l}\text { High Fish } \\
\text { Consumer }\end{array}$ & & $\begin{array}{l}\text { Low Fish } \\
\text { Consumer }\end{array}$ & $\begin{array}{l}\text { Medium Fish } \\
\text { Consumer }\end{array}$ & $\begin{array}{l}\text { High Fish } \\
\text { Consumer }\end{array}$ \\
\hline \multirow[t]{6}{*}{ Buriganga } & $\mathrm{Cr}$ & 120.23 & 8.64 & 10.48 & 15.32 & $2.0^{\mathrm{b}}$ & 0.10 & 0.12 & 0.17 \\
\hline & $\mathrm{Zn}$ & 18.06 & 1.30 & 1.57 & 2.30 & - & 0.07 & 0.09 & 0.13 \\
\hline & $\mathrm{Fe}$ & 26.78 & 1.92 & 2.33 & 3.41 & - & 0.05 & 0.06 & 0.08 \\
\hline & $\mathrm{Pb}$ & 2.69 & 0.19 & 0.23 & 0.34 & $0.21^{c}$ & 0.92 & 1.12 & 1.63 \\
\hline & $\mathrm{Cu}$ & 2.81 & 0.20 & 0.25 & 0.36 & $30^{d}$ & 0.08 & 0.10 & 0.15 \\
\hline & $\mathrm{Ni}$ & 1.43 & 0.10 & 0.12 & 0.18 & $0.3^{\mathrm{e}}$ & 0.09 & 0.10 & 0.15 \\
\hline \multirow[t]{6}{*}{ Turag } & $\mathrm{Cr}$ & 48.13 & 3.46 & 4.19 & 6.13 & 2.0 & 0.04 & 0.00 & 0.00 \\
\hline & $\mathrm{Zn}$ & 46.00 & 3.30 & 4.01 & 5.86 & - & 0.18 & 0.22 & 0.33 \\
\hline & $\mathrm{Fe}$ & 30.86 & 2.22 & 2.69 & 3.93 & - & 0.05 & 0.06 & 0.09 \\
\hline & $\mathrm{Pb}$ & 6.85 & 0.49 & 0.60 & 0.87 & 0.21 & 2.34 & 2.84 & 4.15 \\
\hline & $\mathrm{Cu}$ & 7.32 & 0.53 & 0.64 & 0.93 & 30 & 0.22 & 0.27 & 0.39 \\
\hline & $\mathrm{Ni}$ & 9.03 & 0.65 & 0.79 & 1.15 & 0.3 & 0.54 & 0.66 & 0.96 \\
\hline
\end{tabular}

${ }^{a}$ MTDI: maximum tolerable daily dietary intake

${ }^{b}$ ESADDI: estimated safe and adequate daily dietary intake [78]

ePTDI: provisional tolerable daily intake (60 kg body weight) $[43,44]$

${ }^{d}$ PMTDI: provisional maximum tolerable daily intake[79]

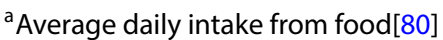

and $\mathrm{Pb}>\mathrm{Ni}>\mathrm{Cu}>\mathrm{Zn}>\mathrm{Fe}>\mathrm{Cr}$ for the Turag River. The values of THQ are less than 1 except $\mathrm{Pb}$, indicating insignificant health hazard results from the intake of a single metal through fish consumption. The THQ value of $\mathrm{Pb}$ is higher than 1 for both Rivers indicating a potential health risk to the fish consumers by consuming the studied fish species. The total THQ values of the metals (sum of individual THQ of metals) due to consumption of fish are 1.30 (3.38), 1.58 (4.05) and 2.31 (5.92) of low, medium and high fish consumers, respectively for the Buriganga River (Turag River) (Table 9). All the THQ values are higher than 1, indicating potential health risks.

Therefore, the possible health risks caused by fish consumption in which heavy metals are accumulated could not be avoided for the citizens. Intake of metals along with other foods and inhalation of dust is not considered in this study. Thus, it is suggested that constant effort to minimize industrial emission (wastewater or similar things) specially in the leather and textile industry should be prioritized. Regular testing of all toxic elements throughout all food products is necessary to assess whether there are any significant health hazards.

\section{Limitations}

The sampling sites considered in this study may not always fully reflect the overall metal defilement condition in water, sediment and species of fish, as Dhaka City's urban region is vast. In addition to the fish species analyzed, people might consume other species that aren't included in this research. To mitigate the possible error, the parameters of exposures to the human body were chosen primarily from applicable research performed for Bangladesh, whereas toxicity specifications for heavy metal were extracted from USEPA recommendations as well as other global research analysis. Nevertheless, we can't eradicate the ambiguity provided by estimating trace metal toxicity of River water usage and fish ingestion in Bangladesh entirely.

\section{Conclusion}

The results of this study show that the water, sediment as well as fish species of the Rivers studied contained various proportions of $\mathrm{Cr}, \mathrm{Zn}, \mathrm{Fe}, \mathrm{Cu}, \mathrm{Pb}$ and Ni. The concentrations of heavy metals in water and sediment exceeded some well-recognized standards. The total emission load is significantly greater in the winter than that in the summer season for both rivers. Contamination factor (CF) revealed that sediment of the Buriganga is moderately polluted by $\mathrm{Cr}$ and the Turag was by $\mathrm{Zn}, \mathrm{Pb}$ and $\mathrm{Cu}$. The Heteropneustes fossilis can be used as a bioindicator for the study of heavy-metal contamination. The metal BCF values show that the $\mathrm{Cr}$ in the fish species is much higher than the most bio-concentrated metals. Based on the results obtained in this study, it can be concluded that the Rivers Buriganga and Turag are seriously contaminated. The usage of water, 
sediment including the ingestion of such River's fish species constitutes a great danger for human health. Thus, constant monitoring and regular analysis of water, sediment and fish in these Rivers are very important to make the necessary steps for the policymakers. It is also highly recommended the longer-lasting treatment of the considered Rivers to lessen the concentration of heavy metals. Moreover, other fish species, flora, fauna and aquatic biota should be monitored to confirm the food safety from heavy-metal contamination and save the consumer from the potential health risks owing to the consumption of their daily food system.

\section{Declarations}

Conflict of interest The authors declare that they have no conflict of interest.

Open Access This article is licensed under a Creative Commons Attribution 4.0 International License, which permits use, sharing, adaptation, distribution and reproduction in any medium or format, as long as you give appropriate credit to the original author(s) and the source, provide a link to the Creative Commons licence, and indicate if changes were made. The images or other third party material in this article are included in the article's Creative Commons licence, unless indicated otherwise in a credit line to the material. If material is not included in the article's Creative Commons licence and your intended use is not permitted by statutory regulation or exceeds the permitted use, you will need to obtain permission directly from the copyright holder. To view a copy of this licence, visit http://creativecommons. org/licenses/by/4.0/.

\section{References}

1. Venkata Mohan S, Nithila P, Jayarama RS (1996) Estimation of heavy metals in drinking water and development of heavy metal pollution index. J Environ Sci Heal Part A Toxic/Hazardous Subst Environ Eng 31(2):283-289

2. Nasehi F, Monavari M, Naderi Gh, Vaezi MA, Madani F (2013) Investigation of heavy metals accumulation in the sediment and body of carp fish in Aras River. Iran J Fish Sci 12(2):398-410

3. Islam MS, Ahmed MK, Raknuzzaman M, Habibullah-Al-Mamun M, Islam MK (2015) Heavy metal pollution in surface water and sediment: A preliminary assessment of an urban River in a developing country. Ecol Indic 48:282-291

4. Mondol MN, Chamon AS, Faiz B, Elahi SF (2011) Seasonal variation of heavy metal concentration in water and plant samples around Tejgaon industrial area of Bangladesh. J Bangladesh Acad Sci 35(1):19-41

5. Kihampa C (2013) Heavy metal contamination in water and sediment downstream of municipal wastewater treatment plants, Dar es Salaam, Tanzania. Int J Environ Sci 3(5):1407-1415

6. Zhang F, Yan X, Zeng C, Zhang M, Shrestha S, Devkota LP et al (2012) Influence of traffic activity on heavy metal concentrations of roadside farmland soil in mountainous areas. Int J Environ Res Public Health 9(5):1715-1731

7. Ashraf W (2006) Levels of selected heavy metals in tuna fish. Arab J Sci Eng. 31(1A):89-92
8. Terra BF, Araújo FG, Calza CF, Lopes RT, Teixeira TP (2008) Heavy metal in tissues of three fish species from different trophic levels in a tropical Brazilian River. Water Air Soil Pollut 187(1-4):275-284

9. United Nations. Goal 6: Clean Water and Sanitation in The Sustainable Development Goals Report. 2017;60.

10. Islam MS, Ahmed MK, Habibullah-Al-Mamun M, Hoque MF (2015) Preliminary assessment of heavy metal contamination in surface sediments from a River in Bangladesh. Environ Earth Sci 73(4):1837-1848

11. Whitehead PG, Bussi G, Peters R, Hossain MA, Softley L, Shawal $S$ et al (2019) Modelling heavy metals in the Buriganga River System, Dhaka, Bangladesh: impacts of tannery pollution control. Sci Total Environ [Internet] 697:134090. https://doi.org/10. 1016/j.scitotenv.2019.134090

12. Paul $R$, Haq $A$ (2010) Challenges of water quality management: case of peripheral Rivers in Dhaka Mega City. In: Presentation from the world water week in Stockholm

13. A shocking further delay in tannery relocation [Internet]. https://www.newagebd.net/article/94630/a-shocking-furth er-delay-in-tanneryrelocation?fbclid=IwAR2/uKp1Xm1 stel4IM YRmWkqt1Sv3f0dGJOZjtUbvfcflrye8RGXVo6WVJk

14. dark-flows-the-River-turag-1587946@www.thedailystar.net [Internet]. https://www.thedailystar.net/star-weekend/envir onment/dark-flows-the-River-turag-1587946?amp

15. Salomons W (1993) Presentation: adoption of common schemes for single and sequential extractions of trace metal in soils and sediments. Int J Environ Anal Chem 51(1-4):3-4

16. Nürnberg HW (1984) The voltammetric approach in trace metal chemistry of natural waters and atmospheric precipitation. Anal Chim Acta. 164(C):1-21

17. Lee CSL, Li XD, Zhang G, Li J, Ding AJ, Wang T (2007) Heavy metals and $\mathrm{Pb}$ isotopic composition of aerosols in urban and suburban areas of Hong Kong and Guangzhou, South ChinaEvidence of the long-range transport of air contaminants. Atmos Environ 41(2):432-447

18. Van-Duijn JRC (1828) Diseases of fishes. The Lancet, vol 9. Narendra Publishing House, Delhi, $\mathrm{p} 651$

19. Jalali JB, Agazade M (2007) Fish intoxication heavy metals and its significance on Public Health. Maane Ketab Pub

20. Li H, Shi A, Li M, Zhang X (2013) Effect of pH, temperature, dissolved oxygen, and flow rate of overlying water on heavy metals release from storm sewer sediments. J Chem

21. Duncan AE, de Vries N, Nyarko KB (2018) Assessment of heavy metal pollution in the sediments of the River Pra and its tributaries. Water Air Soil Pollut. 229(8):272

22. Yahaya M, Mohammad S, Abdullahi B (2010) Seasonal variations of heavy metals concentration in abattoir dumping site soil in Nigeria. J Appl Sci Environ Manag 13(4):9-13

23. Mohiuddin KM, Otomo K, Ogawa Y, Shikazono N (2012) Seasonal and spatial distribution of trace elements in the water and sediments of the Tsurumi River in Japan. Environ Monit Assess 184(1):265-279

24. Close tanneries at Hazaribagh_The Daily Star [Internet]. https://www.thedailystar.net/frontpage/close-tanneries-hazar ibagh-1372036

25. Buriganga River [Internet]. https://en.wikipedia.org/wiki/Burig anga_River

26. Savar tannery ETP stuck by a string_The Business Standard.

27. Saha PK, Hossain M (2010) Geochemical and ecotoxical approach for evaluation of heavy metal pollution in the Buriganga River sediment. In: Bangladesh Geotechnical Conference

28. Islam MS, Chowdhury MAH, Billah MMS, Tusher TR, Sultana N (2012) Investigation of effluent quality discharged from the textile industry of Purbani Group, Gazipur, Bangladesh and it's 
textile industry of Purbani Group, Gazipur, Bangladesh and it's management. Bangladesh J Environ Sci 23:123-130

29. Dhaka Population 2020 (Demographics, Maps, Graphs) [Internet]. https://www.macrotrends.net/cities/20119/dhaka/popul ation

30. Turag River pollution [Internet]. https://en.wikipedia.org/wiki/ Turag_River

31. Ahamad MI, Song J, Sun H, Wang X, Mehmood MS, Sajid M, Su P, Khan AJ (2020) Contamination level, ecological risk, and source identification of heavy metals in the hyporheic zone of the Weihe River, China. Int J Environ Res Public Health 17:1070. https://doi.org/10.3390/ijerph17031070

32. 52 factories operating illegally, polluting Buriganga River [Internet]. https://www.thedailystar.net/country/52-factories-opera ting-illegally-polluting-buriganga-River-environment-1837492

33. Saving Buriganga a farce_The Business Standard [Internet]. https://tbsnews.net/environment/saving-buriganga-farce

34. Cenci RM, Martin JM (2004) Concentration and fate of trace metals in Mekong River Delta. Sci Total Environ 332(1-3):167-182

35. U.S. EPA (2001) Methods for collection, storage and manipulation of sediment for chemical and toxicological analyses: Technical Manual

36. Baki MA, Shojib MFH, Sehrin S, Chakraborty S, Choudhury TR, Bristy MS et al (2020) Health risk assessment of heavy metal accumulation in the Buriganga and Turag River systems for Puntius ticto, Heteropneustes fossilis, and Channa punctatus. Environ Geochem Health [Internet] 42(2):531-543. https://doi.org/10. 1007/s10653-019-00386-4

37. Martin K (2017) ADW: Channa striata:INFORMATION [Internet]. https://animaldiversity.org/accounts/Channa_striata/\#3D29B 1BD-8ED3-11E3-8142-002500F14F28

38. Suresh G, Sutharsan P, Ramasamy V, Venkatachalapathy R (2012) Assessment of spatial distribution and potential ecological risk of the heavy metals in relation to granulometric contents of Veeranam lake sediments, India. Ecotoxicol Environ Saf 84:117-124

39. Turekian KK, Wedepohl KH (1961) Distribution of some major elements of the Earth's crust. Geol Soc Am Bull 72:175-192

40. Loska K, Cebula J, Pelczar J, Wiechuła D, Kwapuliński J (1997) Use of enrichment, and contamination factors together with geoaccumulation indexes to evaluate the content of $\mathrm{Cd}, \mathrm{Cu}$, and $\mathrm{Ni}$ in the Rybnik water Reservoir in Poland. Water Air Soil Pollut 93(1-4):347-365

41. Tomlinson DL, Wilson JG, Harris CR, Jeffrey DW (1980) Problems in the assessment of heavy-metal levels in estuaries and the formation of a pollution index. Helgoländer Meeresuntersuchungen 33(1-4):566-575

42. Islam MS, Han S, Ahmed MK, Masunaga S (2014) Assessment of trace metal contamination in water and sediment of some Rivers in Bangladesh. J Water Environ Technol 12(2):109-121

43. Organization WH et al (1990) Evaluation of certain food additives and contaminants: Thirty-fifth report of the Joint FAO/WHO Expert Committee on Food Additives. In: World Health Organization-Technical Report Series, pp 7-37

44. Heikens A (2006) Arsenic contamination of irrigation water, soil and crops in Bangladesh: Risk implications for sustainable agriculture and food safety in Asia. FAO-RAP Publ 2006/20. 20:2

45. USEPA (1989) Risk Assessment Guidance for Superfund (RAGS): Part A [Internet]. United States Environmental Protection Agency. Washington, DC. http://refhub.elsevier.com/S13826689(14)00311-1/sbref0165

46. US-EPA (2000) Risk-based Concentration Table: Philadelphia PA [Internet]. http://www.epa.gov/reg3hwmd/risk/human/index. htm
47. Islam MS, Ahmed MK, Habibullah-Al-Mamun M (2015) Determination of heavy metals in fish and vegetables in Bangladesh and health implications. Hum Ecol Risk Assess 21(4):986-1006

48. U.S. EPA (2005) Screening level ecological risk assessment protocol for hazardous waste combustion facilities, volume I peer review draft. 2005;3. http://www.epa.gov/epaoswer/hazwaste/ combust/\%0Aeco-risk/voume3/appx-e.pdf

49. Kinniburgh DG, Milne CJ, Benedetti MF, Pinheiro JP, Filius J, Koopal LK et al (1996) Metal ion binding by humic acid: application of the NICA-Donnan model. Environ Sci Technol 30(5):1687-1698

50. Islam MS, Ahmed MK, Raknuzzaman M, Habibullah-Al-Mamun M, Islam MK (2015) Heavy metal pollution in surface water and sediment: a preliminary assessment of an urban River in a developing country. Ecol Indic [Internet] 48:282-291. https://doi.org/ 10.1016/j.ecolind.2014.08.016

51. Yusufu S, Maguta NMM (2019) Lead-based paints and children's PVC toys are potential sources of domestic lead poisoning-a review. Environ Pollut 249:1091-1105

52. Gupta A, Rai DK, Pandey RS, Sharma B (2009) Analysis of some heavy metals in the Riverine water, sediments and fish from River Ganges at Allahabad. Environ Monit Assess 157(1-4):449-458

53. Rahman MS, Saha N, Molla AH (2014) Potential ecological risk assessment of heavy metal contamination in sediment and water body around Dhaka export processing zone, Bangladesh. Environ Earth Sci 71(5):2293-2308

54. Raphael EC, Augustina OC, Frank EO (2011) Trace metals distribution in fish tissues, bottom sediments and water from Okumeshi River in Delta State. Nigeria Environ Res J 5(1):6-10

55. DoE (Department of Environment $G$ of the PR of, Bangladesh) (1997) The Environment Conservation Rules. The Environment Conservation Rules). Bangladesh, pp 179-226

56. World Health Organization (2004) Guidelines for drinking-water quality. World Health Organization, Geneva

57. Islam MS, Ahmed MK, Mamuna MHA, Masunaga S (2015) Assessment of trace metals in fish species of urban Rivers in Bangladesh and health implications. Environ Toxicol Pharmacol 39:347-357

58. Facetti J, Dekov VM, Van Grieken R (1998) Heavy metals in sediments from the Paraguay River: a preliminary study. Sci Total Environ 209(1):79-86

59. Mukai H, Tanaka A, Fujii T, Nakao M (1994) Lead isotope ratios of airborne particulate matter as tracers of long-range transport of air pollutants around Japan. J Geophys Res 99(D2):3717-3726

60. Persaud D, Jaagumagi R., Hayton A (1993) Guidelines for the protection and management of aquatic sediment quality in Ontario. http://hdl.handle.net/10214/15797

61. Rao L, Padmaja G (2000) Bioaccumulation of heavy metals in $M$. cyprinoids from the harbor waters of Visakhapatnam. Bull Pure Appl Sci 19A(2):77-85

62. Ahmed MK, Parvin E, Islam MM, Akter MS, Khan S, Al-Mamun MH (2014) Lead-and cadmium-induced histopathological changes in gill, kidney and liver tissue of freshwater climbing perch Anabas testudineus (Bloch, 1792). Chem Ecol 30(6):532-540

63. Begum A, Mustafa Al, Amin MN, Chowdhury TR, Quraishi SB, Banu N (2013) Levels of heavy metals in tissues of shingi fish (Heteropneustes fossilis) from Buriganga River, Bangladesh. Environ Monit Assess 185(7):5461-5469

64. Islam F, Rahman M, Khan SSA, Ahmed B, Bakar A, Halder M (2013) Heavy metals in water, sediment and some fishes of Karnofuly River, Bangladesh. Pollut Res 32(4):715-721

65. Ahmed MK, Baki MA, Islam MS, Kundu GK, Habibullah-Al-Mamun M, Sarkar SK et al (2015) Human health risk assessment of heavy metals in tropical fish and shellfish collected from the River Buriganga, Bangladesh. Environ Sci Pollut Res 22(20):15880-15890 
66. IARC (1993) International Agency for Research on Cancer, Beryllium, cadmium, mercury and exposure in glass manufacturing industry. VI.58. IARC, Lygon, France. 119238

67. Khan FE, Jolly YN, Islam GMR, Akhter S, Kabir J (2014) Contamination status and health risk assessment of trace elements in foodstuffs collected from the Buriganga River embankments, Dhaka, Bangladesh. Int J Food Contam 1(1):1-8

68. Jezierska B, Witeska M (2007) The metal uptake and accumulation in fish living in polluted waters. Soil Water Pollut Monit Prot Remediat. 2007:107-114

69. Yilmaz $A B$ (2005) Comparison of heavy metal levels of grey mullet (Mugil cephalus L.) and sea bream (Sparus aurata L.) caught in İskenderun Bay (Turkey). Turkish J Vet Anim Sci. 29(2):257-262

70. Petkovšek SAS, Grudnik ZM, Pokorny B (2012) Heavy metals and arsenic concentrations in ten fish species from the Šalek lakes (Slovenia): assessment of potential human health risk due to fish consumption. Environ Monit Assess 184(5):2647-2662

71. Dural M, Göksu MZL, Özak AA (2007) Investigation of heavy metal levels in economically important fish species captured from the Tuzla lagoon. Food Chem 102(1):415-421

72. Ishikawa $Y$, Nakagawa K, Satoh $Y$, Kitagawa T, Sugano H, Hirano T et al (1994) Characteristics of chromate workers' cancers, chromium lung deposition and precancerous bronchial lesions: an autopsy study. Br J Cancer 70(1):160-166

73. FAO (1983) Compilation of legal limits for hazardous substances in fish and fishery product, Library, vol 746. Food and Agriculture Organization of the United Nations, Rome, p 104
74. Dolan S (2008) Guidance Document for Lead in Shellfish [Internet]. Washington, DC. http://www.cfsan.fda.gov/ frf/guid-as. html

75. World Health Organization (WHO) Inorganic Lead. Environmental Health Criteria. [Internet]. Lancet. Geneva (Switzerland); 1995. www.inchem.org/documents/ehc/ehc/ehc165.htm

76. Unclassified N (2009) Technical support document for Nile. ReVision, Washington, DC

77. Abal EG, Bunn SE, Dennison WC (2005) Healthy waterways healthy catchments: making the connection in South East Queensland, Australia. Moreton Bay Waterways and Catchment Partnership

78. Tao Y, Yuan Z, Xiaona H, Wei M (2012) Distribution and bioaccumulation of heavy metals in aquatic organisms of different trophic levels and potential health risk assessment from Taihu lake, China. Ecotoxicol Environ Saf 81:55-64

79. Adolf $L$ (1964) Recommended dietary allowances. Clinical pediatrics, vol 3. National Academies Press, Washington, pp 630-632

80. Duruibe J, Egwurugwu J (2007) Heavy metal pollution and human biotoxic effects. Int J Phys Sci 2(5):112-118

Publisher's Note Springer Nature remains neutral with regard to jurisdictional claims in published maps and institutional affiliations. 